memory is kept green by Sloane Square, Sloane Street and Hans Place. In 1721 he founded for the Society of Apothecaries the botanic garden at Chelsea. He retired from practice in 1741, and died twelve years later at the advanced age of ninety-three.

\section{American Association for the Advancement of Science : Prize Awards}

The Newcomb Cleveland Prize of the American Association has been awarded to Dr. Andrew M. Gleason, assistant professor, Department of Mathematics, Harvard University, for his paper on "Natural Co-ordinate Systems". This is the twenty-fifth award of this Prize, which is worth 1,000 dollars, and is made at the annual meeting of the Association for a paper presented as part of the meeting which represents an outstanding contribution to science.

A prize of 1,000 dollars for an essay on theoretical sociology, provided by a donor who wishes to remain anonymous, was offered by the American Association for the first time in 1951; none of the entries was considered adequate, and no award was made. The prize was offered again for 1952, for essays reporting upon inquiry into the theory of social processes and group behaviour, and has been awarded to Dr. Arnold M. Rose, Department of Sociology, University of Minnesota, for his paper on "The Theory of Social Organization and Disorganization". 'There were some sixty entries. Dr. Rose, who is thirty-two, was associate professor of sociology in Washington University, St. Louis, during 1947-49, and is now associate professor of sociology in the University of Minnesota; he held a Fulbright Fellowship in France during 1951. A series of papers submitted by Stuart C. Dodd, director of the Washington Public Opinion Laboratory, University of Washington, was given honourable mention.

\section{Oceanographical Exhibition in London}

AN exhibition entitled "Exploring the Sea", which has been organized by the Royal Geographical Society and the National Institute of Oceanography, with the co-operation of the Hydrographic Department of the Admiralty, the Institute of Navigation and the British Museum (Natural History), was opened on January 3 at the Royal Geographical Society, Kensington Gore, London, S.W.7; the exhibition will remain open to the general public, admission free, until January 31 (10 a.m.-6 p.m., Sundays excepted). The object of the exhibition is to show how recent scientific developments have very much increased our knowledge of the underwater world, and the display has been arranged in three sections corresponding to work in the three principal fields of oceanographical exploration: "Exploring the Sea Bed", "Life in the Sea" and "The Moving Ocean". In the first section are included an instrument for recording sea temperatures photographically, a deep core, and the equipment for refraction shooting; a deep-sea echo sounder on show is arranged to measure variations of depth in a tank of water. In the section on life in the sea there are many specimens of plankton, a new plankton recorder, and different types of water bottles for taking samples and the temperature of water at depth. In the third section the effect of wind on waves is shown in a model; other exhibits include a working wave-recorder and instruments which record erosion and the graduation and profile of beaches, and current meters and tide recorders, which show how direct measurements of water movements are taken.

\section{Polymer Science: Seminar in University College, London}

EIGHT lectures were given at a seminar on "Polymer Science", held in the Chemistry Department of University College, London, during October 24 December 5, 1952, and they can be classified under three headings : mechanism of formation of polymer; methods of establishing homogeneity, size and shape of polymer; and properties and reactions of macromolecules. In the first section, Dr. C. H. Bamford dealt with the general background of polymerization kinetics and with a study of some co-polymerizations from which it follows that the reactivity of a growing polymer is not solely determined by the terminal grouping. Factors were also discussed which influence the course of polymerizations under conditions such that polymer precipitation occurs. In the second section, Dr. R. A. Kekwick and Dr. P. Johnson reviewed theories and experimental details of the ultracentrifuge, electrophoresis and light-scattering measurements. Methods of determining the shape of macromolecules, particularly proteins, were indicated by Dr. A. Elliott and Dr. C. Robinson, who discussed results obtained with the help of polarized infra-red radiation and a new type of space-filling molecular models. The models are useful for demonstrating stiffness or flexibility of macromolecules. In the third section, on the properties and reactions of macromolecules, Dr. L. R. G. Treloar lectured on statistical thermodynamics of polymer-liquid interaction. Difficulties were pointed out which prevent the straightforward extension of the Flory-Huggins treatment to such systems as water and polar fibrous materials. Furthermore, the influence of external stress on equilibrium swelling was discussed. G. Stainsby, M. L. R. Harkness and Dr. A. Wassermann described the properties and reactions of ash-free gelatin and actomyosin. Prof. M. Stacey dealt with chemical and immunological properties of degraded dextran. Methods for breaking down these macromolecules and for fractionating the resultant products were also outlined. Each of the eight lectures was followed by a discussion, which was facilitated by making available, in advance, short abstracts indicating not only the main topic, but also the general background and important literature references.

\section{Application of Science in the Textile Industries}

THE inaugural lecture "Science in Industry" which Sir Ben Lockspeiser delivered in the new premises of the Textile Institute, Manchester, on October 24, emphasized that the application of science to industry is the primary means of providing the power of adaptation to new conditions on which the economic survival of Great Britain depends. After illustrating this by reference to the part science has played in the introduction and application of the new man-made fibres and their effect on the older fibres, Sir Ben turned to the importance of the small firm in the effective application of science to industry. A recent survey in a small town engaged mainly in the light industries showed that only one-third of the firms had anyone with a special responsibility for advising on scientific and technical problems, and only half of these advisers had any technical qualifications. Sir Ben believed that a survey being conducted in the Manchester area would show that it is rare for textile firms employing five hundred people or less to employ a science or engineering graduate : only in 